\title{
Stabilizing Effect of Metal Carboxylates of Balanites aegyptiaca Seed Oil (BSO) on Poly(vinyl chloride)
}

\author{
Olujinmi M. Folarin ${ }^{1}$, Ighodalo C. Eromosele ${ }^{1} \&$ Catherine O. Eromosele ${ }^{1}$ \\ ${ }^{1}$ Chemistry Department, University of Agriculture, Abeokuta, Nigeria \\ Correspondence: Olujinmi M. Folarin, Chemistry Department, University of Agriculture, Abeokuta, Nigeria. Tel: \\ 234-806-253-0595. E-mail: mofedara@yahoo.com
}

Received: August 29, 2012 Accepted: January 10, 2013 Online Published: January 18, 2013

doi:10.5539/enrr.v3n2p1 URL: http://dx.doi.org/10.5539/enrr.v3n2p1

\begin{abstract}
Thermal stabilization studies of poly(vinyl chloride) (PVC) in the presence of lead, cadmium, barium, calcium and zinc carboxylates of Balanites aegyptiaca seed oil (BSO) were carried out in air and under nitrogen atmosphere in the temperature range $170-190{ }^{\circ} \mathrm{C}$. The stabilizing effects of the metal carboxylates were assessed by measurements of the time for degradation to attain $1 \%$ conversion, $t_{\mathrm{DH}}$ and the corresponding rate of degradation, $\mathrm{R}_{\mathrm{DH}}$. Kinetic parameters determined under nitrogen were higher than those determined in air indicating that PVC degraded less in air within the temperature range employed. All metal carboxylates stabilized PVC under the conditions employed for the study and showed a relative order of stabilization of $\mathrm{Cd}-\mathrm{BSO}>\mathrm{Ba}-\mathrm{BSO}>\mathrm{Pb}-\mathrm{BSO}>\mathrm{Ca}-\mathrm{BSO}>\mathrm{Zn}$-BSO. At higher temperature $\left(190{ }^{\circ} \mathrm{C}\right)$ deleterious effect of $\mathrm{Zn}$-BSO manifested after prolonged heating. This is corroborated by data obtained from measurements of intrinsic viscosity of degraded PVC samples and thermogravimetric analysis. Synergistic effect was not exhibited by the compositions of binary mixtures of $\mathrm{Ca} / \mathrm{Zn}$ carboxylates investigated while $\mathrm{Ba} / \mathrm{Cd}$ carboxylates at 1: 9 ratio exhibited synergistic effect on PVC stabilization.
\end{abstract}

Keywords: poly(vinyl chloride), Balanites aegyptiaca, thermal stabilization, metal carboxylates, thermogravimetric analysis

\section{Introduction}

Improvement in chemical and fabrication technologies has led to production of many useful domestic, industrial products and materials from poly(vinyl chloride) (PVC) with consequent increase in tonnage use. There is virtually no aspect of world economy PVC has not found application, however, this could not have been possible without the use of thermal stabilizers due to intrinsic thermal instability of the polymer. PVC is processed to useful materials at temperature above $160{ }^{\circ} \mathrm{C}$ (Folarin et al., 2012) although it has glass transition temperature of $70{ }^{\circ} \mathrm{C}$ (Folarin \& Sadiku, 2011). At elevated temperature, it degrades via thermal dehydrochlorination that is auto-accelerated by the evolved $\mathrm{HCl}$ which results in severe discolouration arising from the formation of conjugated double bonds in the polymer chain and consequent loss of some properties (Tong et al., 2011; Toliwal \& Patel, 2009; Liu et al., 2008; Steenwijk et al., 2006). Autocatalytic nature of thermal degradation of PVC and its poor thermal stability make the use of thermal stabilizers during processing imperative (Boussoum et al., 2006). Many compounds (organic and inorganic) have been used as PVC thermal stabilizers (Folarin \& Sadiku, 2011) however, metal carboxylates stand out and many had been prepared from pure fatty acids and seed oils (Essien et al., 2012; Folarin et al., 2011a; Folarin \& Enikanoselu, 2010; Fang et al, 2009; Egbuchunam et al., 2007; Okieimen et al., 2006; Egbuchunam et al., 2005; Gonzalez-Ortiz et al., 2005; Balkose et al., 2001). Seed oils will remain viable source of PVC thermal stabilizers as a result of their fatty acid contents and availability from different plant sources. Our earlier report (Folarin et al., 2011a) revealed that metal carboxylates of Ximenia americana seed oil (XSO) and Balanites aegyptiaca seed oil (BSO) are thermally stable within the temperature range for processing PVC. This work aims at investigating thermal stabilizing effects of some metal carboxylates of Balanites aegyptiaca seed oil (BSO) on PVC as a way of harnessing its potential in Nigeria. 


\section{Materials and Methods}

The poly(vinyl chloride) obtained from Sigma-Aldrich Co (USA) (Mn, $0.9 \times 10^{5}$ ) was purified and the metal carboxylates were prepared as earlier reported (Folarin et al., 2011a; Folarin et al., 2011b). Thermal degradation of PVC was carried out in the presence of the carboxylates in the temperature range $170{ }^{\circ} \mathrm{C}-190{ }^{\circ} \mathrm{C}$ under nitrogen and in air as earlier described (Folarin et al., 2011b).

For viscosity measurements, the degraded PVC samples were purified by solution in cyclohexanone and precipitation in methanol. The precipitated polymers were filtered off and air-dried. Dilute solution viscosity measurements of undegraded and degraded samples were carried out in cyclohexanone using Ubbelohde capillary viscometer mounted in a thermo stated water bath at $30 \pm 0.1{ }^{\circ} \mathrm{C}$. The intrinsic viscosity, [ $\left.\eta\right]$ was determined from Huggins equation:

$$
\eta / c=[\eta]+K^{\prime}[\eta]^{2} c
$$

The stabilizing effects of the metal carboxylates were evaluated from the ratios of intrinsic viscosity of PVC samples degraded in the presence of additives, $[\eta]$ to viscosity of undegraded sample, $[\eta]_{0}$ i.e., $[\eta] /[\eta]_{0}$. Thermogravimetric study of PVC degradation in the presence of the metal carboxylates was conducted using Perkin-Elmer Pyris 6 thermal gravimetric analyzer programmed at a heating rate of $10^{\circ} \mathrm{C} \mathrm{min}^{-1}$ up to a temperature of $550^{\circ} \mathrm{C}$ under nitrogen.

\section{Results and Discussion}

The conversions in PVC degradation under nitrogen at $190{ }^{\circ} \mathrm{C}$ in the presence of $3 \mathrm{wt} \%$ metal carboxylates of BSO is shown in Figure 1. Time for degradation to attain $1 \%$ conversion, $t_{\mathrm{DH}}$ and corresponding rate of degradation at $1 \%$ conversion, $\mathrm{R}_{\mathrm{DH}}$ were used to evaluate effect of the carboxylates, the results are presented in Table 1. In the absence of additives, $\mathrm{t}_{\mathrm{DH}}$ and $\mathrm{R}_{\mathrm{DH}}$ values for PVC degradation increased with temperature in the range $170-190^{\circ} \mathrm{C}$. $\mathrm{t}_{\mathrm{DH}}$ and $\mathrm{R}_{\mathrm{DH}}$ are $34 \mathrm{~min}$ and $3.0 \times 10^{-2} \% \mathrm{~min}^{-1}$ respectively at $190^{\circ} \mathrm{C}$.

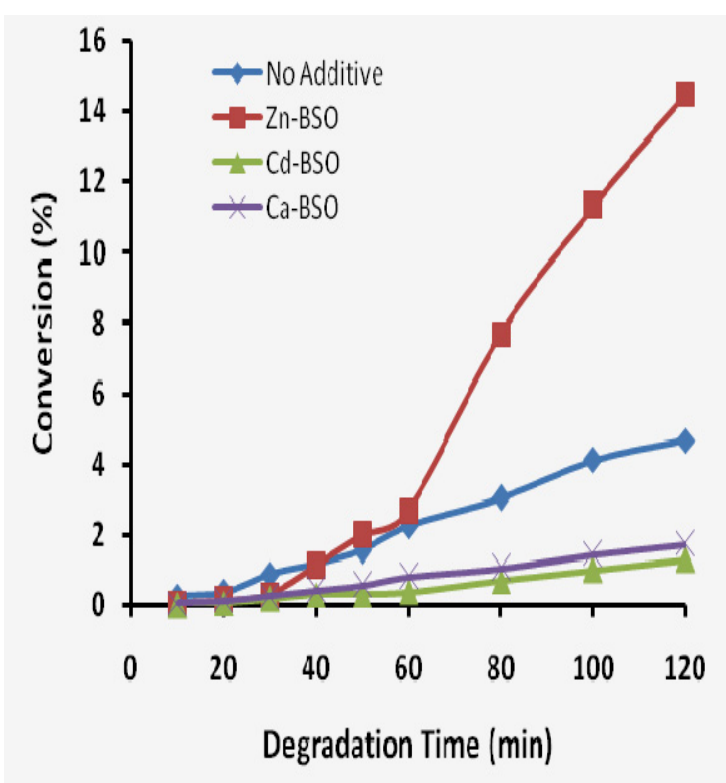

Figure 1. Plots of dehydrochlorination of PVC in the presence of $3 \mathrm{wt} \%$ metal carboxylates of BSO under $\mathrm{N}_{2}$ at $190^{\circ} \mathrm{C}$ 
Table 1. Kinetic parameters for dehydrochlorination of PVC under nitrogen in the presence of metal carboxylates of BSO

\begin{tabular}{lcccc}
\hline Additive $(3 \mathrm{wt} \%)$ & Temperature $\left({ }^{\circ} \mathrm{C}\right)$ & $\mathrm{t}_{\mathrm{DH}}(\mathrm{min})$ & $10^{2} \mathrm{R}_{\mathrm{DH}}\left(\% \mathrm{~min}^{-1}\right)$ & Rate Constant $\mathrm{k}\left(\mathrm{min}^{-1}\right)$ \\
\hline None & 170 & 78 & 1.76 & 1.10 \\
& 180 & 56 & 1.90 & 1.19 \\
& 190 & 34 & 3.00 & 1.88 \\
Zn-BSO & 180 & 70 & 4.17 & 2.61 \\
& 190 & 40 & 8.15 & 5.09 \\
Cd-BSO & 180 & $>120$ & & 0.96 \\
& 190 & 103 & 1.53 & 1.14 \\
Pb-BSO & 180 & $>120$ & & \\
Ba-BSO & 190 & 86 & 1.82 & 0.96 \\
& 180 & $>120$ & & 1.25 \\
Ca-BSO & 190 & 94 & 1.54 & \\
\hline
\end{tabular}

Metal carboxylates can interact with evolved $\mathrm{HCl}$ especially at early stage of dehydrochlorination and this is one of the basis of their application as PVC thermal stabilizers. Mechanism of stabilization of PVC consists of $\mathrm{HCl}$ trapping by the unsaturated fatty acid moieties and substitution of labile chlorine atoms by carboxylate groups (Folarin et al., 2012). All metal carboxylates of BSO, including Zn-BSO, exhibited stabilizing effect on PVC. In the presence of $3 \mathrm{wt} \% \mathrm{Zn}-\mathrm{BSO}$, degradation of PVC at 180 and $190{ }^{\circ} \mathrm{C}$ is lower having $\mathrm{t}_{\mathrm{DH}}$ and $\mathrm{R}_{\mathrm{DH}}$ values of 40 min and $8.15 \times 10^{-2} \% \mathrm{~min}^{-1}$ respectively at the latter temperature. This is in contrast to accentuation of degradation by Zn-XSO earlier reported (Folarin et al., 2012). However, it is in agreement with reported stabilizing effect of zinc soap of khaya seed oil at this temperature (Okieimen \& Eromosele, 2000).

Under the same experimental conditions, all metal carboxylates of BSO exhibited higher stabilizing effect than those of XSO earlier reported (Folarin et al., 2012). Specifically, at $190{ }^{\circ} \mathrm{C}, \mathrm{Cd}-\mathrm{BSO}$ is more active by as much as $69 \%$ than Cd-XSO based on $t_{\mathrm{DH}}$ values. Our earlier report (Folarin et al., 2011a) showed that metal carboxylates of BSO are more stable thermally than those of XSO at temperature range normally employed in processing PVC. It was also reported much earlier (Okieimen \& Ebhoaye, 1992) that unsaturation confers instability on metal soaps of unsaturated acids. Thus, the observed differences in stability of PVC in the presence of metal carboxylates of XSO and BSO may be due to differences in levels of unsaturation in the fatty acid moiety of the oils. Based on iodine value of $158.3 \mathrm{gI}_{2} 100 \mathrm{~g}^{-1}$, XSO is a drying oil while $\mathrm{BSO}$ is a semi-drying oil with iodine value of $102.6 \mathrm{gI}_{2} 100 \mathrm{~g}^{-1}$ (Folarin et al., 2011b). The order of stabilization by metal carboxylates of BSO is: $\mathrm{Cd}-\mathrm{BSO}>\mathrm{Ba}-\mathrm{BSO}>\mathrm{Pb}-\mathrm{BSO}>\mathrm{Ca}-\mathrm{BSO}>\mathrm{Zn}-\mathrm{BSO}$.

The order of stabilization shown above is supported partly by studies on the metal soaps of khaya seed oil, jatropha seed oil (Okieimen \& Eromosele, 2000) and wild olive seed oil (Ximenia americana) (Folarin et al., 2012). Thus, it may be deduced that for different seed oils, the order of stabilization of PVC by the metal carboxylates is a function of intrinsic aggregate chemical properties of their fatty acid constituents. 


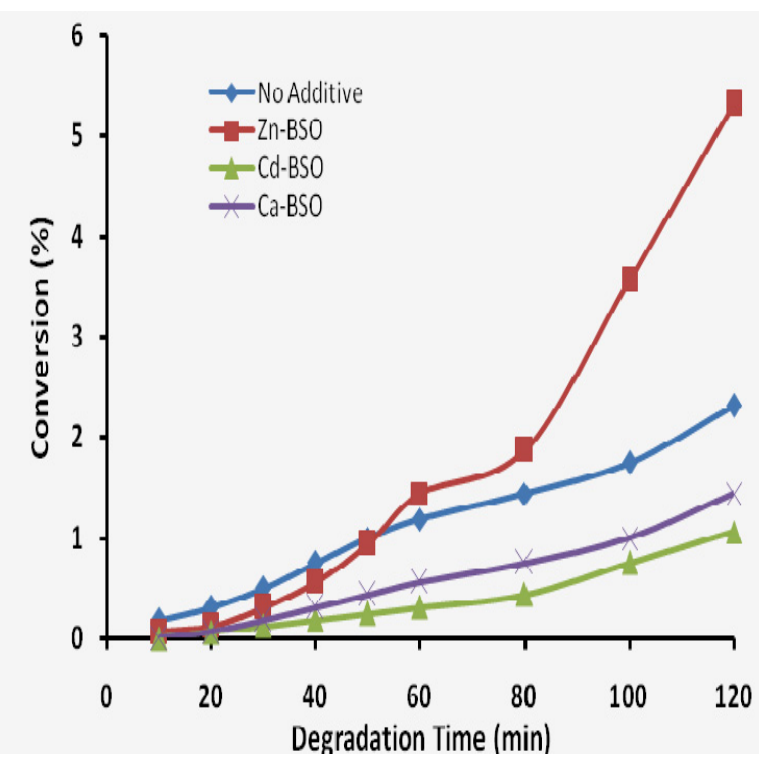

Figure 2. Plots of dehydrochlorination of PVC in the presence of $3 \mathrm{wt} \%$ metal carboxylates of BSO in air at $190{ }^{\circ} \mathrm{C}$

Figure 2 shows the conversions in PVC degradation in air at $190{ }^{\circ} \mathrm{C}$ in the presence of $3 \mathrm{wt} \%$ metal carboxylates of BSO. Time for degradation to attain $1 \%$ conversion, $\mathrm{t}_{\mathrm{DH}}$ and the corresponding rate of degradation at $1 \%$ conversion, $\mathrm{R}_{\mathrm{DH}}$ are presented in Table 2 . At $190{ }^{\circ} \mathrm{C}$ degradation temperature, $\mathrm{t}_{\mathrm{DH}}$ values range from $55 \mathrm{~min}$ for sample containing $\mathrm{Zn}$ carboxylate to $107 \mathrm{~min}$ for sample containing $\mathrm{Cd}$ carboxylate.

Table 2. Kinetic parameters for dehydrochlorination of PVC in air in the presence of metal carboxylates of BSO

\begin{tabular}{lcccc}
\hline Additive $(3 \mathrm{wt} \%)$ & Temperature $\left({ }^{\circ} \mathrm{C}\right)$ & $\mathrm{t}_{\mathrm{DH}}(\mathrm{min})$ & $10^{2} \mathrm{R}_{\mathrm{DH}}\left(\% \mathrm{~min}^{-1}\right)$ & Rate Constant $\mathrm{k}\left(\mathrm{min}^{-1}\right)$ \\
\hline None & 180 & 120 & 1.00 & 0.63 \\
& 180 & 56 & 1.90 & 1.19 \\
& 190 & 53 & 3.00 & 1.88 \\
Zn-BSO & 180 & 96 & 2.00 & 1.25 \\
& 190 & 55 & 4.00 & 2.50 \\
Cd-BSO & 180 & $>120$ & & 1.06 \\
& 190 & 107 & 1.70 & \\
Pb-BSO & 180 & $>120$ & & 0.93 \\
& 190 & 102 & 1.48 & 0.81 \\
Ba-BSO & 180 & $>120$ & & 0.94 \\
Ca-BSO & 190 & 105 & 1.30 & \\
\hline
\end{tabular}

The corresponding $\mathrm{R}_{\mathrm{DH}}$ values are $1.7 \times 10^{-2} \% \mathrm{~min}^{-1}$ for Cd carboxylate and $4.0 \times 10^{-2} \% \mathrm{~min}^{-1}$ for $\mathrm{Zn}$ carboxylate. The order of stabilization by metal carboxylates of $\mathrm{BSO}$ is: $\mathrm{Cd}-\mathrm{BSO}>\mathrm{Ba}-\mathrm{BSO}>\mathrm{Pb}-\mathrm{BSO}>\mathrm{Ca}-\mathrm{BSO}>\mathrm{Zn}-\mathrm{BSO}$ based on $t_{\mathrm{DH}}$ values. This order is consistent with the one observed for the carboxylates under nitrogen. A comparison of Tables 1 and 2 shows that PVC degraded less in air than under nitrogen at the temperature range investigated. All kinetic parameters determined are higher in nitrogen than in air. This could be due to some other reactions such as oxidation of polyene occurring along with dehydrochlorination in air. The oxidation of polyene interrupts elimination of $\mathrm{HCl}$ from the polymer backbone thereby hindering degradation. Figures 3 and 4 show the plots of relative intrinsic viscosity $[\eta] /[\eta]_{0}$ versus degradation time for PVC stabilized by $3 \mathrm{wt} \%$ metal carboxylates of $\mathrm{BSO}$ at $190^{\circ} \mathrm{C}$ under nitrogen and in air respectively. 


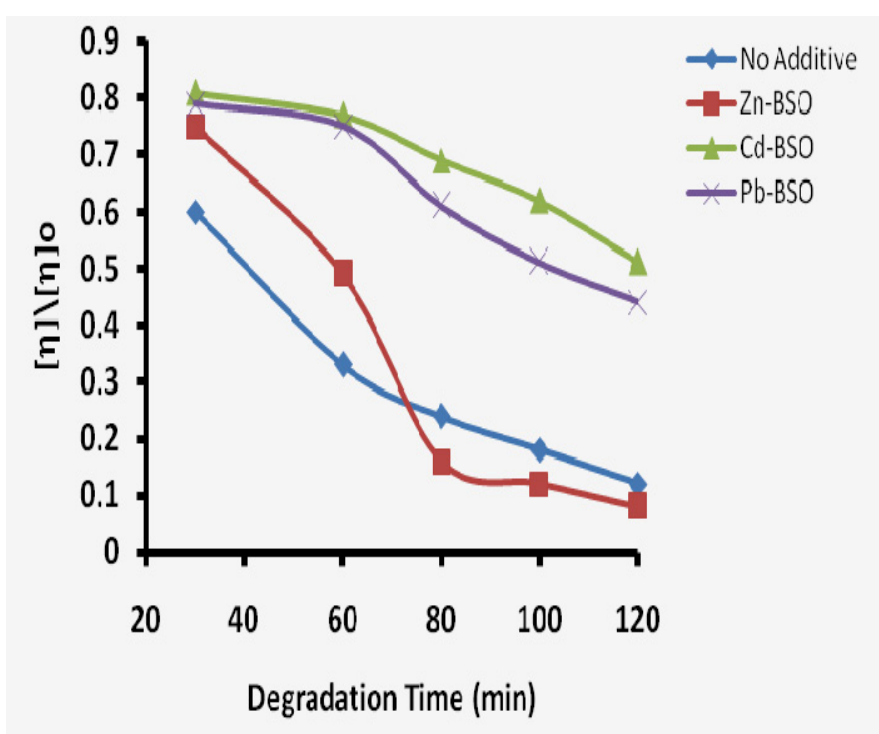

Figure 3. Plots of relative intrinsic viscosity vs degradation time for PVC stabilized by $3 \mathrm{wt} \%$ metal carboxylates of $\mathrm{BSO}$ at $190^{\circ} \mathrm{C}$ under $\mathrm{N}_{2}$

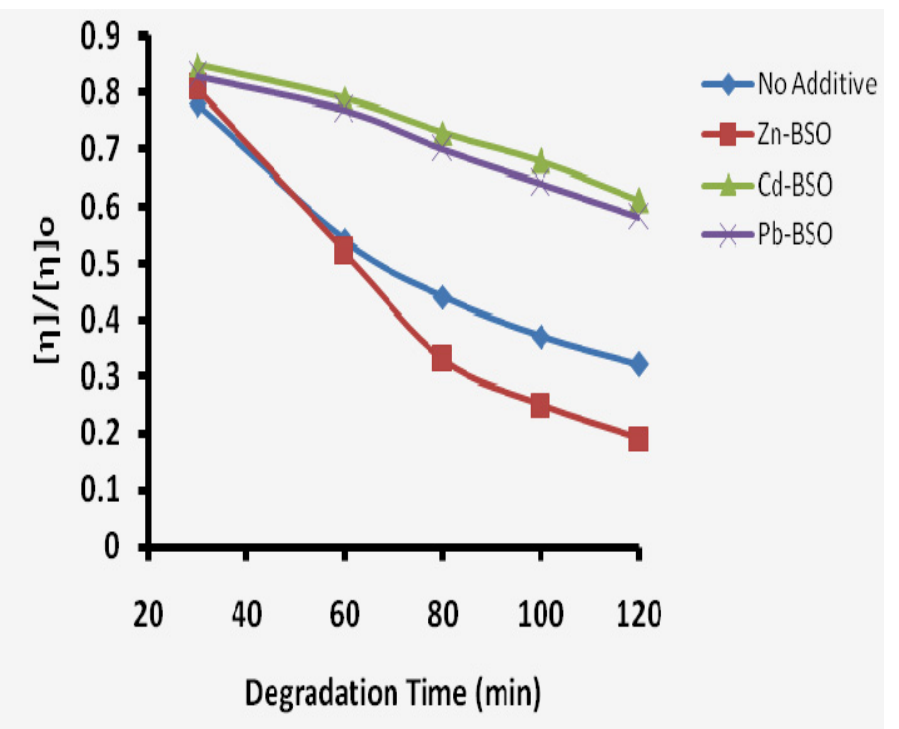

Figure 4. Plots of relative intrinsic viscosity vs degradation time for PVC stabilized by $3 \mathrm{wt} \%$ metal carboxylates of BSO at $190^{\circ} \mathrm{C}$ in air

$[\eta]_{0}$ is the intrinsic viscosity of undegraded polymer and $[\eta]$, the value after varying degradation time. In the Figures, it is obvious that relative intrinsic viscosity decreases with increase in degradation time. The deleterious effect of Zn-BSO on degradation of PVC after prolonged heating and considerable stabilization of PVC by other metal carboxylates are evident in the figures. The plots for barium and calcium carboxylates of BSO are not shown in Figures 3 and 4, however, their values lie between those of Cd-BSO and Pb-BSO (Tables 3 and 4). 
Table 3. Intrinsic viscosity of PVC after degradation at $190{ }^{\circ} \mathrm{C}$ under nitrogen in the presence of barium and calcium carboxylates of BSO

\begin{tabular}{lccc}
\hline Additive (3 wt\%) & Degradation Time (min) & {$[\mathrm{y}]\left(\mathrm{dlg}^{-1}\right)$} & {$[\mathrm{y}] /[\mathrm{g}]_{\mathrm{o}}$} \\
\hline Ba-BSO & 30 & 1.25 & 0.80 \\
& 60 & 1.17 & 0.75 \\
& 80 & 0.96 & 0.62 \\
& 100 & 0.86 & 0.55 \\
Ca-BSO & 120 & 0.71 & 0.45 \\
& 30 & 1.24 & 0.79 \\
& 60 & 1.14 & 0.73 \\
& 80 & 0.96 & 0.58 \\
& 100 & 0.73 & 0.47 \\
& 120 & 0.64 & 0.41 \\
\hline
\end{tabular}

Table 4. Intrinsic viscosity of PVC after degradation at $190{ }^{\circ} \mathrm{C}$ in air in the presence of barium and calcium carboxylates of BSO

\begin{tabular}{lccc}
\hline Additive (3 wt\%) & Degradation Time (min) & {$[\mathrm{y}]\left(\mathrm{dlg}^{-1}\right)$} & {$[\mathrm{y}] /[\mathrm{g}]_{\mathrm{o}}$} \\
\hline Ba-BSO & 30 & 1.32 & 0.85 \\
& 60 & 1.22 & 0.78 \\
& 80 & 1.11 & 0.71 \\
& 100 & 1.04 & 0.67 \\
Ca-BSO & 120 & 0.94 & 0.60 \\
& 30 & 1.28 & 0.82 \\
& 60 & 1.19 & 0.76 \\
& 80 & 1.07 & 0.69 \\
& 100 & 0.98 & 0.62 \\
& 120 & 0.87 & 0.56 \\
\hline
\end{tabular}

To further establish the stabilizing effects of individual carboxylates on PVC and to determine the synergistic effects of mixtures of the carboxylates on PVC thermal stabilization, thermogravimetric analysis was performed. The thermogram of PVC samples containing the metal carboxylates is shown in Figure 5.

The temperatures at which maximum degradation, $t_{\max }$ and various extents of degradation occurred were used to evaluate the stabilizing effects of the additives. The result of the analysis is presented in Table 5. It shows that all the carboxylates, including Zn-BSO stabilized PVC, however, Cd-BSO is the most effective. This result is consistent with the results of kinetics of degradation and viscosity measurements. 


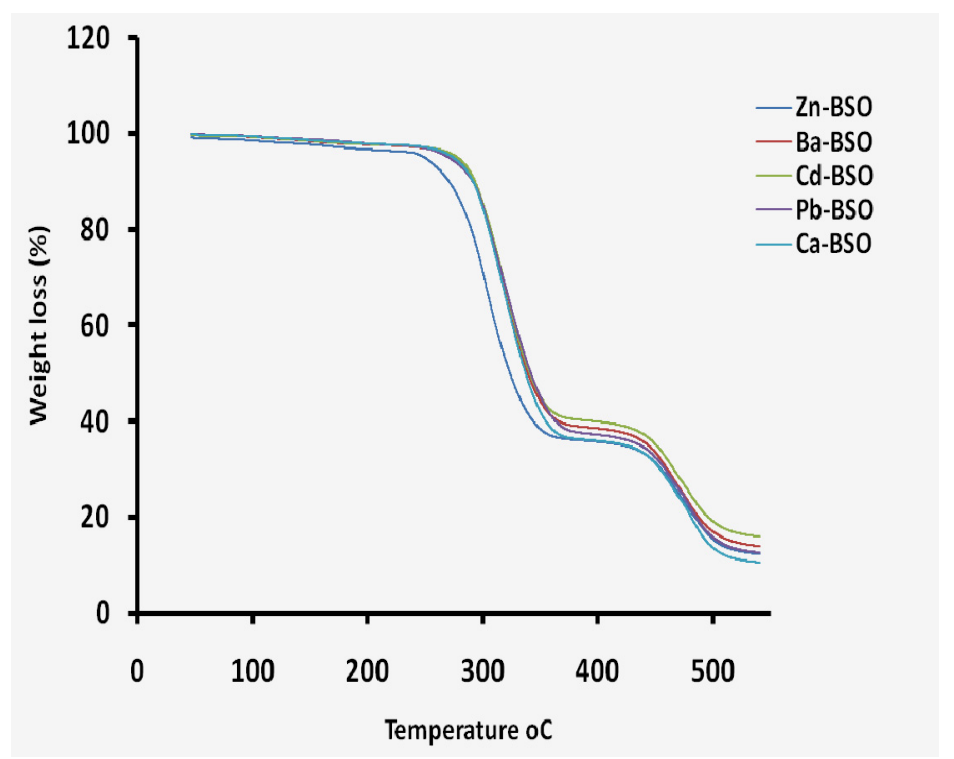

Figure 5. Thermogram of PVC samples containing metal carboxylates of BSO

Table 5. Evaluation of relative thermal stability of PVC stabilized with metal carboxylates of BSO

\begin{tabular}{llcccc}
\hline $\begin{array}{l}\text { Additive } \\
(3 \mathrm{wt} \%)\end{array}$ & $\mathrm{t}_{\max }$ & $5 \%$ & $10 \%$ & $30 \%$ & $50 \%$ \\
\hline None & 298.0 & 234.9 & 275.9 & 308.6 & 330.0 \\
Zn-BSO & 307.8 & 266.9 & 288.1 & 319.0 & 341.5 \\
$\mathrm{Cd}-\mathrm{BSO}$ & 324.7 & 295.3 & 310.6 & 335.4 & 358.1 \\
$\mathrm{~Pb}-\mathrm{BSO}$ & 322.4 & 292.8 & 308.0 & 332.5 & 354.1 \\
$\mathrm{Ba}-\mathrm{BSO}$ & 323.3 & 290.7 & 307.6 & 334.0 & 358.0 \\
$\mathrm{Ca}-\mathrm{BSO}$ & 321.1 & 280.4 & 304.6 & 332.2 & 355.7 \\
\hline
\end{tabular}

Mixed metal carboxylates, usually in the form of $\mathrm{Ca} / \mathrm{Zn}$ and $\mathrm{Ba} / \mathrm{Cd}$ carboxylates had been reported to exhibit synergistic effect. Synergism had been attributed to fast exchange reactions between the chlorides of $\mathrm{Zn}$ or $\mathrm{Cd}$ and carboxylates of $\mathrm{Ca}$ and $\mathrm{Ba}$ (Balkose et al., 2001). Synergistic effects of $\mathrm{Ca} / \mathrm{Zn}$ and $\mathrm{Ba} / \mathrm{Cd}$ mixed carboxylates of the metal carboxylates were investigated using different compositions and the result is presented in Table 6 . All compositions of binary mixtures of $\mathrm{Ca} / \mathrm{Zn}$ carboxylates investigated did not exhibit synergistic effect since all the $t_{\max }$ values obtained were lower than that of Ca-BSO (Table 6) and this means that effect of the compositions is addition. For the mixture of $\mathrm{Ba} / \mathrm{Cd}$ carboxylates, $10 \mathrm{wt} \% \mathrm{Ba} / \mathrm{Cd}$ mixtures exhibited synergistic effect with the highest $\mathrm{t}_{\max }$ value of $325.9^{\circ} \mathrm{C}$. However, this is contrary to $90 \mathrm{wt} \% \mathrm{Ba} / \mathrm{Cd}$ mixtures earlier reported for carboxylates of XSO (Folarin et al., 2012). This observed difference could be attributed to difference in fatty acids composition of the two oils. BSO is a semi-drying oil while XSO is a drying oil. The level of unsaturation in the fatty acids appears to have a great effect on the chemical reactivity of the carboxylates and this requires further investigation.

Many researchers have reported on the enhancement of stabilizing effect of metal carboxylates in the presence of epoxidized oils (Egbuchunam et al., 2007; Boussoum et al., 2006; Gonzalez-Ortiz et al., 2005). The effect of the native and epoxidized oils on zinc carboxylate of the oil was investigated and the result is presented in Table 7. The compositions of the mixture investigated were $10 \mathrm{wt} \%$ and $20 \mathrm{wt} \%$ oil/zinc carboxylate. The results show that epoxidized oil was more effective than the native in enhancing the stabilizing effect of zinc carboxylate based on $t_{\max }$ and temperatures at which various extents of degradation were attained. The effect is concentration-dependent. 
Table 6. Evaluation of relative thermal stability of PVC stabilized $(3 \% \mathrm{w} / \mathrm{w})$ with binary mixtures of metal carboxylates of BSO

\begin{tabular}{lccccc}
\hline Ca-BSO/ & \multicolumn{5}{c}{ Temperatures at which various extents of degradation were attained $\left({ }^{\circ} \mathrm{C}\right)$} \\
$\mathrm{Zn}-\mathrm{BSO}$ & $\mathrm{t}_{\max }$ & $5 \%$ & $10 \%$ & $30 \%$ & $50 \%$ \\
\hline $90 \mathrm{wt} \% \mathrm{Ca}-\mathrm{BSO}$ & 318.0 & 286.2 & 303.2 & 328.1 & 349.4 \\
$50 \mathrm{wt} \% \mathrm{Ca}-\mathrm{BSO}$ & 315.0 & 286.9 & 300.5 & 323.9 & 346.6 \\
$10 \mathrm{wt} \% \mathrm{Ca}-\mathrm{BSO}$ & 312.4 & 281.4 & 297.1 & 321.7 & 345.4 \\
$\mathrm{Ba}-\mathrm{BSO} /$ & & & & \\
$\mathrm{Cd}-\mathrm{BSO}$ & & & & & \\
$90 \mathrm{wt} \% \mathrm{Ba}-\mathrm{BSO}$ & 323.0 & 291.2 & 309.0 & 333.3 & 355.8 \\
$50 \mathrm{wt} \%$ Ba-BSO & 323.3 & 290.3 & 308.5 & 333.0 & 356.1 \\
$10 \mathrm{wt} \%$ Ba-BSO & 325.9 & 292.3 & 311.0 & 355.9 & 358.4 \\
\hline
\end{tabular}

Table 7. Evaluation of relative thermal stability of PVC stabilized with mixtures of oil and Zn-BSO

\begin{tabular}{llcccc}
\hline Additive & \multicolumn{5}{c}{ Temperatures at which various extents of degradation were attained $\left({ }^{\circ} \mathrm{C}\right)$} \\
$(3 \mathrm{wt} \%)$ & $\mathrm{t}_{\max }$ & $5 \%$ & $10 \%$ & $30 \%$ & $50 \%$ \\
\hline $10 \mathrm{wt} \%$ BSO & 291.4 & 250.0 & 274.3 & 302.6 & 327.1 \\
$10 \mathrm{wt} \%$ EBSO & 294.5 & 250.7 & 275.6 & 304.6 & 327.9 \\
$20 \mathrm{wt} \%$ BSO & 293.9 & 264.1 & 277.8 & 303.9 & 329.3 \\
$20 \mathrm{wt} \%$ EBSO & 298.5 & 269.3 & 288.2 & 308.8 & 332.8 \\
\hline
\end{tabular}

\section{Conclusions}

Metal carboxylates of BSO stabilized PVC in air and under nitrogen atmosphere in the temperature range 170 $190{ }^{\circ} \mathrm{C}$. Based on the parameters of kinetic of degradation determined, PVC degraded less is air compare to nitrogen atmosphere. This may be attributed to oxidation of polyene that occurred along side dehydrochlorination in air. The order of stabilization was, $\mathrm{Cd}-\mathrm{BSO}>\mathrm{Ba}-\mathrm{BSO}>\mathrm{Pb}-\mathrm{BSO}>\mathrm{Ca}-\mathrm{BSO}>\mathrm{Zn}-\mathrm{BSO}$. This is corroborated by results of intrinsic viscosity measurements of degraded PVC samples and thermogravimetric analysis. The relative intrinsic viscosity of degraded PVC decreased linearly with increase in degradation time and suggested absence of secondary reactions of polyene. Of all compositions of mixed metal carboxylates of $\mathrm{Ca} / \mathrm{Zn}$ and $\mathrm{Ba} / \mathrm{Cd}$ investigated for synergism, only $\mathrm{Ba} / \mathrm{Cd}$ at 1:9 ratio exerted synergistic effect on PVC stabilization. This is however contrary to $9: 1$ ratio of $\mathrm{Ba} / \mathrm{Cd}$ of XSO earlier reported. This suggests that the fatty acid composition of oils is of great importance in determining reactivity of metal carboxylates and this requires further investigations. The epoxidized oil is more effective in enhancing the stabilizing effect of $\mathrm{Zn}$ carboxylate and the effectiveness is concentration-dependent.

\section{Acknowledgements}

The authors wish to appreciate the Department of Chemistry, University of Zululand, Kwa Dlangezwa, Republic of South Africa for thermogravimetric analyses of the PVC samples. The financial support of University of Agriculture, Abeokuta Nigeria in this regard is gratefully acknowledged and appreciated.

\section{References}

Balkose, D., Gokcel, H. I., \& Goktepe, S. E. (2001). Synergism of Ca/Zn soaps in poly(vinyl chloride) thermal stability. Eur. Polym. J., 37, 1191-1197. http://dx.doi.org/10.1016/S0014-3057(00)00233-0

Boussoum, M. O., Atek, D., \& Belhaneche-Bensemra, N. (2006). Interactions between poly(vinyl chloride) stabilized with epoxidized sunflower oil and food stimulants. Polym. Degrad. Stab., 91, 579-587. http://dx.doi.org/10.1016/j.polymdegradstab.2005.05.036

Egbuchunam, T. O., Balkose, D., \& Okieimen, F. E. (2007). Effect of zinc soaps of rubber seed oil (RSO) and/or epoxidized rubber seed oil (ERSO) on the thermal stability of PVC plastigels. Polym. Degrad. Stab., 92, 1572-1582. http://dx.doi.org/10.1016/j.polymdegradstab.2007.05.002 
Egbuchunam, T. O., Okieimen, F. E., \& Aigbodion, A. I. (2005). Studies in the thermal stability of metal soaps of parkia seed oil. Chem. Tech. J., 1, 18 - 23.

Essien, E. A., Umoren, S. A. Essien, E. E., \& Udoh, A. P. (2012). Preparation and evaluation of Cucumeropsis mannii Naud. seed oil metallic soaps as driers in gloss paint. J. Mater. Environ. Sci., 3, 477-484. http://www.jmaterenvironsci.com

Fang, L., Song, Y., Zhu, X., \& Zheng, Q. (2009). Influence of lanthanum stearate as a co-stabilizer on stabilization efficiency of calcium/zinc stabilizers to poly(vinyl chloride). Polym. Degrad. Stab., 94, 845-855. http://dx.doi.org/10.1016/j.polymdegradstab.2009.01.024

Folarin, O. M., \& Enikaoselu, O. N. (2010). Evaluation of the effect of temperature on the stability of metal soaps of Trichosanthes cucumerina seed oil. EJEAFChe, 9, 1604-1610. http://ejeafche.uvigo.es/component/option,com_docm

Folarin, O. M., \& Sadiku, E. R. (2011). Thermal stabilizers for poly(vinyl chloride): A review. Int. J. Phys. Sci., 6, 4323-4330.

Folarin, O. M., Eromosele, I. C., \& Eromosele, C. O. (2011a). Relative thermal stability of metal soaps of Ximenia americana and Balanites aegyptiaca seed oils. Sci. Res. Essays., 6, 1922-1927.

Folarin, O. M., Eromosele, I. C., \& Eromosele, C. O. (2011b). Thermal degradation of poly(vinyl chloride) in the presence of Ximenia americana and Balanites aegyptiaca seed oils. Afr. J. Pure Appl. Chem., 5, 346-355.

Folarin, O. M., Eromosele, I. C., \& Eromosele, C. O. (2012). Thermal stabilization of poly(vinyl chloride) by metal carboxylates of Ximenia americana seed oil under inert condition. J. Mater. Environ. Sci., 3, 507-514.

Gonzalez-Ortiz, L. J., Arellano, M., Jasso, C. F., Mendizabal, E., \& Sanchez-Pena, M. J. (2005). Thermal stability of plasticized poly(vinyl chloride) compounds stabilized with pre-heated mixtures of calcium $\begin{array}{llllll}\text { and/or zinc stearates. Polym. Degrad. Stab., } & \text { 90, }\end{array}$ http://dx.doi.org/10.1016/j.polymdegradstab.2005.04.013

Liu, J., Chen, G., \& Yang, J. (2008). Preparation and characterization of poly(vinyl chloride)/layered double hydroxide nanocomposites with enhanced thermal stability. Polymer, 49, 3923-3927. http://dx.doi.org/10.1016/j.polymer.2008.07.014

Okieimen, F. E., \& Ebhoaye, J. E. (1992). Thermal dehydrochlorination of PVC in the presence of metal soaps derivatives from rubber seed oil. Eur. Polym. J., 28, 1423-1425. http://dx.doi.org/10.1016/0014-3057(92)90286-B

Okieimen, F. E., \& Eromosele, C. O. (2000). Stabilizing effect of derivatives of khaya seed oil on the thermal degradation of PVC. Eur. Polym. J., 36, 525 - 537. http://dx.doi.org/10.1016/S0014-3057(99)00099-3

Okieimen, F. E., Egbuchunam, T. O., Bakare, O. I., \& Sogbaike, C. E. (2006). Investigation on the thermal stability of Ba, Cd, Ca and Zn soaps of rubber seed oil. J. Chem. Soc. Nig., 31, 136-140.

Steenwijk, J., Langerock, R., van Es, D. S., van Haveren, J., Geus, J. W., \& Jenneskens, L. W. (2006). Long-term heat stabilization by (natural) polyols in heavy metal- and zinc-free poly(vinyl chloride). Polym. Degrad. Stab., 91, 52-59. http://dx.doi.org/10.1016/j.polymdegradstab.2005.04.027

Toliwal, S. D., \& Patel, K. (2009). Utilization of by-products of oil processing industries for PVC stabilizers. $J$. Sci. Ind. Research., 68, 229-234. http://nopr.niscair.res.in/handle/123456789/3136

Tong, M., Chen, H., Yang, Z., \& Wen, R. (2011). The effect of Zn-Al-Hydrotalcites composited with calcium stearate and $\beta$-diketone on the thermal stability of PVC. Int. J. Mol. Sci., 12, 1756-1766. 